\title{
Profil Keterampilan Proses Sains (KPS) Mahasiswa Fisika pada Materi Listrik Magnet
}

\author{
Yaspin Yolanda \\ STKIP PGRI Lubuklinggau \\ Jalan Mayor Toha, Kelurahan Air Kuti, Lubuklinggau Sumatera Selatan, Indonesia \\ ‘E-mail: yaspinyolanda@ymail.com
}

\begin{abstract}
Abstrak
Penelitian ini mendeksripsikan profil keterampilan proses sains (KPS) mahasiswa Pendidikan Fisika STKIP PGRI Lubuklinggau pada materi listrik magnet. Subjek penelitian adalah mahasiswa semester III yang mengambil mata kuliah listrik magnet. Pengambilan sampel dilakukan secara purpossive sampling. Metode Deskriptif kualitatitif. Data dianalisa secara kualitatif dan kuantitatif menggunakan instrumen berupa tes diagnosis KPS. Berdasarkan hasil data penelitian KPS listrik magnet mahasiswa pada pokok bahasan Listrik magnet disimpulkan (1) Keterampilan proses sains listrik magnet adalah terampil, dan (2) Solusi untuk menyelesaikan permasalahan ketersediaan aspek KPS adalah melatih dan dilatih dengan pendekatan KPS listrik magnet mahasiswa agar ketersediaan aspek KPS dapat muncul/tersedia. Rata-rata persentase peningkatan KPS yakni, keterampilan observasi $82 \%$, keterampilan klasifikasi $80 \%$, keterampilan interpretasi $85 \%$, keterampilan prediksi $78 \%$, keterapilan merencanakan percobaan atau penyelidikan $88 \%$, keterampilan menggunakan alat dan bahan $87 \%$, keterampilan menerapkan konsep atau prinsip $80 \%$, keterampilan berkomunikasi $85 \%$, keterampilan mengajukan pertanyaan 84 , dan keterampilan berhipotesis $79 \%$. Sehingga terjadinya peningkatan signifikan $82,8 \%$.
\end{abstract}

Kata kunci: Keterampilan Proses Sains, Listrik Magnet

\begin{abstract}
This study describes the profile of the science process skills (KPS) of STKIP PGRI Lubuklinggau students on magnetic electric material. The subjects of the research were the third semester students who took magnet electricity courses. Sampling was done by purposive sampling. The research method used was Qualitative Positive Descriptive Method. Data were analyzed qualitatively and quantitatively using an instrument in the form of a KPS diagnosis test. Based on the results of KPS research on student electricity magnet on the subject of Electric magnet, it can be concluded that (1) The skills of the science process of magnet electricity are skilled, and (2) The solution to solve the problem of availability of KPS aspects is to train and be trained with the KPS approach to magnetized student electricity so that the availability of KPS aspects can appear / available. The average percentage increase in KPS are, $82 \%$ observation skills, $80 \%$ classification skills, $85 \%$ interpretation skills, $78 \%$ prediction skills, $88 \%$ experimental planning or investigation skills, $87 \%$ skills using tools and materials, $80 \%$ skills in applying concepts or principles \%, 85\% communication skills, 84 question asking skills, and $79 \%$ hypothesized skills. The research findings indicate that there is a significant increase in $82.8 \%$.
\end{abstract}

Keywords: Science Process Skills, Magnetic Power

\section{PENDAHULUAN}

Listrik magnet pada hakikatnya bertujuan untuk mengembangkan peserta didik dalam mengenal gejala alam, memahami gejala dan proses kejadian alam yang terjadi secara ilmiah dengan pendekatan metode ilmiah. Hal ini didasari oleh tujuan pembelajaran sains, yakni mengamati, memahami dan memanfaatkan gejala-gejala alam yang melibatkan materi (zat) dan energi, hal ini sejalan dengan pendapat Serway, \& Jewett (2009) dan Nasution (2012). Kemampuan observasi dan eksperimentasi ini lebih ditekankan pada melatih kemampuan berpikir ilmiah yang mencakup melakukan 
percobaan dalam pengukuran atau membuktikan hipotesis secara ilmiah. Mata pelajaran listrik magnet yang disampaikan melalui proses penyelidikan ilmiah, dapat melatih dan mengembangkan keterampilan proses sains mahasiswa. Hal inilah yang menjadi karakteristik dari pelajaran listrik magnet.

Pembelajaran listrik magnet sangat berperan dalam meningkatkan keterampilan proses sains (KPS) mahasiswa. KPS merupakan pendekatan proses dalam pembelajaran listrik magnet didasarkan atas pengamatan terhadap apa yang dilakukan oleh seorang ilmuwan. Kurikulum 2013 (K-13) sangat tepat dalam menerapkan keterampilan proses sains sehingga pembelajaran listrik magnet mampu mengarahkan pada pengembangan aspek keterampilan misalnya keterampilan dalam memproses pengetahuan, menemukan dan mengembangkan sendiri fakta, konsep, dan nilai-nilai yang diperlukan. Mahasiswa pendidikan listrik magnet seyogyanya harus memiliki pemahaman tentang kurikulum 2013, hal ini sejalan dengan pemikiran Nasution (2012). Sehingga mahasiswa diberikan kesempatan untuk langsung terlibat dalam aktivitas dan pengalaman ilmiah seperti yang dilakukan/dialami oleh ilmuwan. Dengan demikian mahasiswa dididik dan dilatih untuk terampil dalam memperoleh dan mengolah informasi melalui aktivitas berpikir dengan mengikuti prosedur (metode) ilmiah, seperti terampil melakukan pengamatan, pengukuran, merancang dan merakit instrumen percobaan, menguji hipotesis melalui percobaan pengklasifikasian, penarikan kesimpulan, dan pengkomunikasian hasil temuan secara lisan dan tertulis. Ada beberapa alasan yang melandasi perlunya diterapkan pendekatan keterampilan proses dalam kegiatan belajar sehari-hari, yaitu perkembangan ilmu pengetahuan berlangsung semakin pesat sehingga tak mungkin lagi dosen mengajarkan semua fakta dan konsep kepada mahasiswa. Mahasiswa akan mudah memahami konsepkonsep yang rumit dan abstrak jika disertai dengan contoh-contoh nyata yang mereka alami dalam kehidupan sehari-hari, Hilpan
(2014).

Berdasarkan observasi dan wawancara ke dosen dan mahasiswa yang dilakukan peneliti di STKIP PGRI Lubuklinggau yang mengambil mata kuliah listrik magnet masih dipandang sebagai mata kuliah yang menakutkan, banyak rumusan yang harus dihafal, mahasiswa belum menemukan makna, kebermanfaatan ketika diajarkan oleh dosen, mahasiswa kesulitan dalam hitung, kesulitan memahami konsep listrik magnet yang diajarkan, masih banyak yang mengalami miskonsepsi dalam belajar listrik magnet khususnya listrik magnet, penggunaan laboratorium dalam pembelajaran listrik magnet tidak pernah dilaksanakan. Selanjutnya mahasiswa merasa malas untuk membaca bahan teks listrik magnet yang digunakan karena banyak rumusan, tidak menarik karena listrik magnet masih belum kontekstual dan belum memunculkan keterampilan proses sains peserta didik. Fakta keterampilan proses sains tersebut sejalan dengan pendapat Hilpan (2014) dan Pratama, Sudirman, \& Andriani (2014). Berdasarkan observasi di lapangan bahwa banyak pendidik yang masih menggunakan bahan ajar konvensional, yaitu bahan ajar tinggal pakai dan tinggal beli tanpa ada upaya menyusun sendiri. Dengan demikian, sangat memungkinkan jika bahan ajar yang digunakan tidak kontekstual, tidak menarik, monoton dan tidak sesuai dengan kebutuhan mahasiswa.

Chaedar. A (2009) menyatakan bahwa pembelajaran kontekstual adalah pembelajaran yang mampu membangun kebermaknaan (construktivism), pembelajaran berbasis penemuan (inquiry), belajar bersama (learning community), pembelajaran berdasarkan konteksnya (modelling), penilaiannya autentik dan mampu mengukur tingkat kemampuan mahasiswa (authentic assesment). Pembelajaran kontekstual mampu memberikan kesempatan kepada mahasiswa untuk bertanya (questioning), dan membimbing mahasiswa dalam mereview kembali materi yang telah diajarkan (reflection) seperti yang diungkapkan Yolanda (2018).

Materi listrik magnet tentang listrik 
magnet merupakan materi yang sangat kontekstual, sangat menarik dan bermanfaat dan mahasiswa lebih banyak mengalami dan menemukan listrik sebagai kebutuhan pokok untuk penerangan, menghidupkan alat-alat elektronik yang bisa membantu pekerjaan manusia. Melalui mata kuliah listrik magnet diharapkan perlu mengembangkan keterampilan proses sains mahasiswa melalui pendekatan kontekstual menggunakan bahan ajar sehingga dapat meningkatkan hasil belajar mahasiswa dan meningkatkan keterampilan proses sains mahasiswa, menarik minat mahasiswa untuk membaca dan bisa mengukur pengetahuan, keterampilan dan sikap mahasiswa dalam pembelajaran listrik magnet. Oleh karena itu, melalui penelitian ini peneliti akan menganalisa profil keterampilan proses sains mahasiswa dalam mata kuliah listrik magnet.

Penelitian ini difokuskan pada profil keterampilan proses sains mahasiswa STKIP PGRI Lubuklinggau program studi pendidikan fisika. Materi listrik magnet yang dimaksud dalam penelitian ini adalah materi-materi ajar listrik magnet yang membahas tentang konsep dasar magnet, induksi magnet, gaya magnetik dan elektrodinamika.

\section{METODE PENELITIAN}

Metode penelitian pada dasarnya merupakan cara ilmiah untuk mendapatkan data dengan tujuan dan kegunaan tertentu. Penelitian ini adalah penelitian deskriptif dengan menggunakan metode kualitatif menurut Sugiyono (2008). Penelitian deskriptif pada umumnya dilakukan dengan tujuan utama, yaitu menggambarkan secara sistematis fakta dan karakteristik objek atau subjek yang diteliti secara tepat, menurut Setiawan (2009).

Teknik pengumpulan data menggunakan triangulasi yakni dokumentasi, wawancara dan tes diagnosis awal dan diagnosis akhir setelah diberi perlakuan untuk mengukur KPS mahasiswa. Sumber data dari penelitian ini adalah hasil dari hasil soal tes diagnosis terdapat dalam tes diagnosis dan lembar wawancara dilakukan untuk melihat permasalahan KPS disetiap tingkat kemampuan mahasiswa dan memberikan solusi dalam menyelesaikan permasalahan KPS mahasiswa. Lembar wawancara akan divalidasi terdahulu oleh dosen mata pelajaran listrik magnet dan dosen program studi listrik magnet. Data yang diperoleh kemudian disusun, dan dianalisis sesuai kemunculan aspek keterampilan proses sains menurut Tomlinson (2011).

Adapun tahap analisis data tersebut adalah sebagai berikut:

1. Obsevasi, Emzir (2011) menyatakan bahwa adapun tes diagnosis dan lembar Observasi terdapat pada bahan ajar harus divalidasi oleh ahli materi. Pada penelitian ini dilakukan cara mengukur ketersediaan aspek keterampilan proses sains sebagai berikut (a) Mengubah data kualitatif ke kuantitatif setiap indikator-indikator pada masing-masing aspek uji keterampilan proses sains perlu di beri skor dengan bobot 1, 2, 3 dan 4. Setiap respon yang benar diberi skor dengan bobot tertentu, umpamanya masing-masing 1 untuk pokok uji observasi di atas yang berarti jumlah skornya 4. Dan untuk respon yang lebih kompleks, Gall, Borg, \& Gall (1996) menyebutkan dalam membuat pertanyaan, dapat diberikan skor bervariasi berdasarkan tingkat kesulitannya. Umpamanya pertanyaan berlatar belakang hipotesis diberi skor 3; pertanyaan apa, mengapa, bagaimana diberi skor 2; pertanyaan yang meminta penjelasan diberi skor 1. (b) Setelah melakukan pemberian skor pada setiap indikator ketersedian aspek KPS, selanjutnya kita jumlahkan kemunculan indikator keterampilan proses sains tersebut dan menghitung persentase frekuensi kemunculan seluruh aspek, Nurhasanah (2016). Selanjutnya (c) Kategorikan aspek keterampilan proses sains mahasiswa ke dalam tabel interpretasi tes diagnostik berikut: 
Tabel 1. Interpretasi KPS Listrik magnet mahasiswa pada Bahan Ajar

\begin{tabular}{ll}
\hline $\begin{array}{l}\text { Kategori } \\
\text { Kemampuan } \\
\text { Aspek KPS }\end{array}$ & $\begin{array}{l}\text { Rentang Skor Aspek } \\
\text { KPS }\end{array}$ \\
\hline Tidak Terampil & $10 \leq x \leq 17,5$ \\
Cukup Terampil & $17,5 \leq x \leq 25$ \\
Terampil & $25 \leq x \leq 32,5$ \\
Sangat Terampil & $32,5 \leq x \leq 40$ \\
\hline
\end{tabular}

2. Melakukan uji validasi oleh dosen ahli mengenai isi dan konstruksi lembar observasi keterampilan proses sains dan validasi instrumen. (a) Tes Diagnostik, Data yang diperoleh dari hasil diagnostik terhadap mahasiswa direduksi dengan mahasiswa dengan mengelompokkan mahasiswa yang menerapkan aspek KPS. Tes yang digunakan pada penelitian ini berupa tes diagnostik dan soal tes LKS, kemudian menganalisis kemunculan aspek KPS pada keduanya. Gay \& Geoffrey (2009) menjabarkan dalam literaturnya Adapun cara mengukur ketersedian Aspek Keterampilan Proses Sains dilakukan dengan beberapa cara, yakni mengubah data kualitatif ke kuantitatif setiap indikatorindikator pada masing-masing aspek uji keterampilan proses sains perlu di beri skor dengan bobot 1, 2, 3 dan 4. Setiap respon yang benar diberi skor dengan bobot tertentu, umpamanya masing-masing 1 untuk pokok uji observasi di atas yang berarti jumlah skornya 4. Dan untuk respon yang lebih kompleks, misalnya membuat pertanyaan, dapat diberi skor bervariasi berdasarkan tingkat kesulitannya. Umpamanya pertanyaan berlatar belakang hipotesis diberi skor 3; pertanyaan apa, mengapa, bagaimana diberi skor 2; pertanyaan yang meminta penjelasan diberi skor 1. (b) Setelah melakukan pemberian skor pada setiap indikator ketersedian aspek KPS, selanjutnya kita jumlahkan kemunculan indikator keterampilan proses sains tersebut dan menghitung persentase frekuensi kemunculan. (c) Kategorikan aspek keterampilan proses sains mahasiswa ke dalam tabel interpretasi tes diagnostik menurut Yanti (2013) dan Yolanda (2015) sebagai berikut:

Tabel 2. Interpretasi Hasil Tes Diagnostik dengan Reasoning Aspek KPS Listrik magnet mahasiswa

\begin{tabular}{ll}
\hline $\begin{array}{l}\text { Kategori } \\
\text { Kemampuan } \\
\text { Aspek KPS }\end{array}$ & $\begin{array}{l}\text { Rentang Skor Aspek } \\
\text { KPS }\end{array}$ \\
\hline Tidak Terampil & $0 \leq x \leq 10$ \\
Kurang Terampil & $10 \leq x \leq 32,5$ \\
Cukup Terampil & $32,5 \leq x \leq 55$ \\
Terampil & $55 \leq x \leq 77,5$ \\
Sangat Terampil & $77,5 \leq x \leq 100$ \\
\hline
\end{tabular}

3. Melakukan uji validasi oleh dosen ahli mengenai isi dan konstruksi lembar observasi keterampilan proses sains dan validasi instrumen. Pada penelitian KPS ini, bahwa instrumen penelitian termasuk tes diagnostik, lembar kerja mahasiswa (LKS), lembar observasi aspek keterampilan proses sains (KPS) dan pedoman wawancara telah divalidasi oleh ahli metodologi penelitian. Wawancara dilakukan untuk melihat permasalahan KPS di setiap tingkat kemampuan mahasiswa menggunakan pedoman wawancara yang sudah disiapkan oleh peneliti. Pedoman wawancara telah divalidasi selanjutnya data wawancara dikumpulkan, informasi yang didapat dianalisis dengan memberikan deskripsi berdasarkan masing-masing aspek. Keterampilan Proses Sains (KPS) untuk kemudian menganalisis kemunculan indikator KPS.

4. Display Data, setelah data direduksi, maka langkah selanjutnya adalah mendisplaykan data. Dalam penelitian kualitatif, penyajian data bisa dilakukan dalam bentuk uraian singkat, bagan, hubungan antar kategori, flowchart dan sejenisnya. Display data paling sering digunakan untuk menyajikan data dalam penelitian kualitatif adalah dengan teks yang bersifat naratif. Dalam melakukan display data, selain dengan teks yang naratif, juga dapat berupa grafik, matrik, network (jejaring kerja), dan chart. Dalam penelitian ini, display data dilakukan dengan mentabulasikan data berdasarkan kelompoknya masing-masing, hal ini sejalan dengan pendapat Sugiyono (2008). 
Pada penelitian ini, penyajian data (display data) dilakukan dengan mentabulasikan data dengan menggunakan diagram kolom, tabel, dan gambar berdasarkan kategori masing-masing mahasiswa berkemampuan tinggi (KT), berkemampuan sedang (KS), dan berkemampuan rendah (KR). Penyajian data pada hasil tes diagnostik dengan reasoning mahasiswa terdiri dari interprestasi hasil tes diagnostik aspek KPS, hasil tes diagnostik dengan reasoning mahasiswa, persentase hasil tes diagnostik dengan reasoning mahasiswa rata-rata persentase hasil tes diagnostik dengan reasoning mahasiswa, dan hasil jawaban tes diagnostik dengan reasoning aspek KPS mahasiswa. Penyajian data pada hasil observasi yang dilakukan observer terdiri dari interprestasi observasi aspek KPS, hasil observasi aspek KPS listrik magnet mahasiswa, dan persentase hasil observasi aspek KPS. Penyajian data terdiri dari ketersediaan aspek KPS, sehingga data yang disajikan akan lebih jelas dan mudah dipahami, Yolanda (2015).

\section{PEMBAHASAN}

Berdasarkan hasil analisa penilaian Keterampilan Proses Sains mahasiswa menggunakan tes diagnosis diperoleh KPS listrik magnet mahasiswa agar ketersediaan aspek KPS mahasiswa dapat muncul/tersedia. Adapun jenis keterampilan proses sains yang muncul menggunakan instrumen tes diagnosis adalah sebagai berikut:

\section{Keterampilan Observasi}

Keterampilan melakukan pengamatan seluruh alat indra secara proporsional dalam menggambarkan objek atau mengukur karakteristik benda-banda yang diamati, kholifah (2015). Keterampilan mengamati misalnya mahasiswa harus menggunakan indra mata dalam membaca prinsip kerja dinamo sepeda seperti gambar dibawah ini.

Contoh:

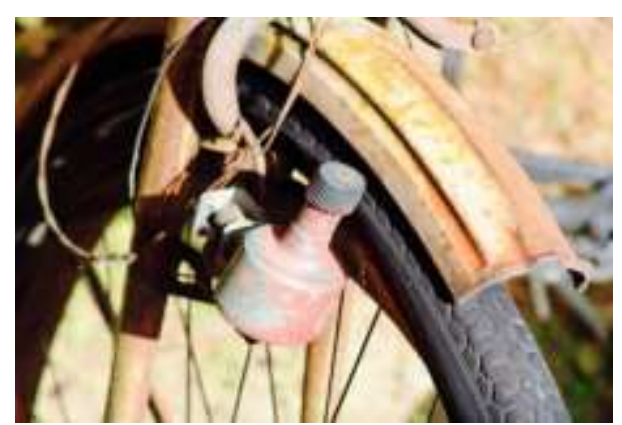

Cara kerja dinamo hampir mirip dengan cara kerja generator, yaitu prinsip kerjannya sama-sama menggunakan arus bolak-balik Alternating Current (AC) dan arus searah Direct Current (DC).

Perbedaan dinamo dan generator terletak pada dua komponen utama dinamo, yaitu rotor (bagian yang bergerak) dan stator (bagian yang diam). Manfaat dinamo pada sepeda adalah sebagai sumber arus listrik sehingga lampu sepeda dapat menyala selama sepeda sedang bergerak. Dinamo hanya dapat bekerja selama roda sepeda berputar. Dari pernyataan diatas. Prinsip kerja dinamo adalah ...

a. Mengubah energi bunyi menjadi energi gerak.

b. Mengubah energi bunyi menjadi energi gerak.

c. Mengubah energi gerak menjadi energi listrik.

d. Mengubah energi cahaya menjadi energi gerak.

e. Mengubah energi cahaya menjadi energi bunyi.

\section{Keterampilan Klasifikasi}

Keterampilan Mengelompokkan sesuatu berdasarkan karakter yang sama berdasarkan standar kriteria tertentu menurut Kholifah (2015) mengatakan bahwa misalkan mahasiswa terampil dalam mengidentifikasi perbedaan dan persamaan antara berbagai objek yang diamati, mahasiswa terampil dalam mengklasifikasi jenis-jenis, misalnya mencari nilai hambatan pengganti yang sama dari susunan hambatan.

Contoh: Lima buah hambatan listrik yang sama disusun bergantian menjadi lima jenis rangkaian seperti gambar berikut. 


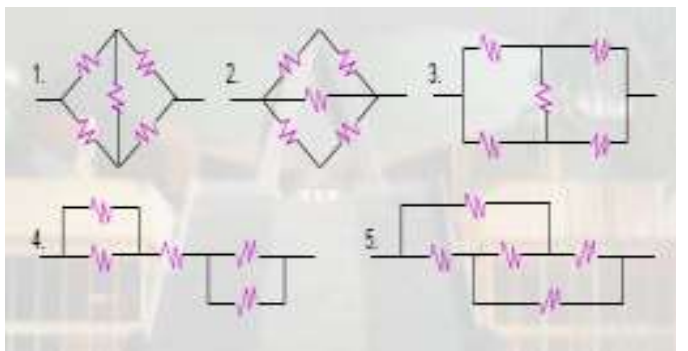

Menurut pengamatan Anda, rangkaianrangkaian yang memiliki hambatan pengganti yang sama adalah gambar :
A. 1, 2 dan 3
C. 1,3 dan 5
B. 2, 3 dan 4
D. 3,4 dan 5
E. 2, 3 dan 5
Berikan alasan saudara

\section{Keterampilan Interpretasi}

Keterampilan menafsirkan hasil pengamatan ialah menarik kesimpulan sementara dari data yang didapt secara berulang dan di interpretasikan dalam deskripsikan dengan membuat kesimpulan seperti yang disampaikan Rustaman, Dirdjosoemarto, Yudianto, Achmad, Subekti, Rochintaniawati \& Nurjhani, (2005). Misalkan mahasiswa terampil dalam menginterpretasi data gambar mengenai cara-cara menghilangkan sifat kemagnetan seperti pada Contoh berikut.

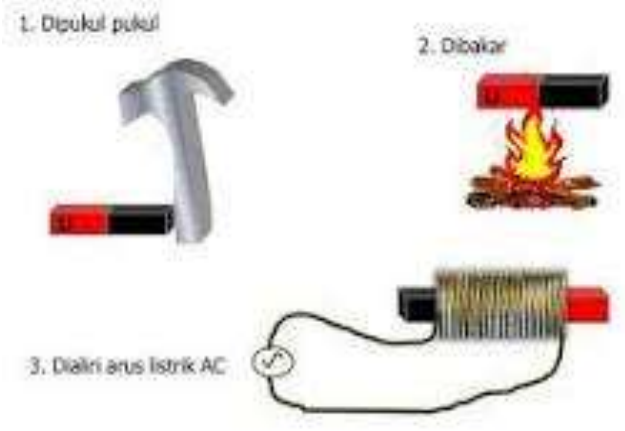

Dari gambar diatas Langkah 1: Dijatuhkan/ dipukul-pukul. Dengan dijatuhkan akan menyebabkan magnet tersebut kehilangan kemagnetannya sedikit demi sedikit. Langkah 2: Pemanasan pada magnet. Pemanasan pada magnet dapat menyebabkan perubahan susunan magnet elementernya. Dan langkah 3: Dialiri arus listrik bolak-balik (AC).

\section{Keterampilan Mengajukan Pertanyaan}

Keterampilan mengajukan pertanyaan merupakan keterampilan dasar yang harus dimiliki mahasiswa sebelum mempelajari suatu masalah lebih lanjut. Rustaman, dkk (2005). Pertanyaan yang diajukan dapat meminta penjelasan, tentang apa, mengapa, bagaimana, atau menanyakan latar belakang sehingga munculnya konsep, rumus listrik magnet, aplikasi materi pelajaran dalam konsteks yang mereka alami. Misalnya mengapa burung gereja bertengger di kabel listrik bertegangan tinggi tidak tesentrum?, mengapa ketika tangan kita basah memegang peralatan elektronik mudah tesentrum?.

\section{Keterampilan Prediksi}

Yolanda (2018) mendefinikan keterampilan prediksi adalah keterampilan dalam memperkirakan berdasarkan kecenderungan data-data hasil pengamatan. Misalnya mahasiswa terampil dalam memprediksikan terang, redup dan matinya sebuah lampu yang tersusun dalam rangkaian lampu, mahasiswa mampu memprediksikan hasil temuanya berdasarkan data-data yang diperoleh dalam praktikum.
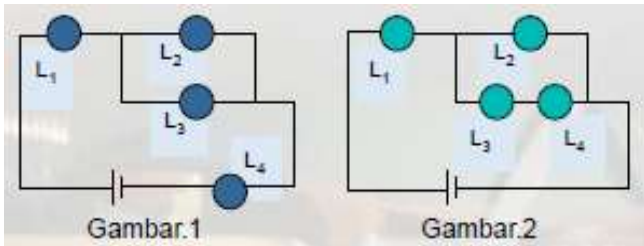

Ketika saudara bereksperimen pada empat buah lampu (L) yang sama, mula-mula dirangkaikan seperti gambar 1. Kemudian oleh seorang mahasiswa rangkaian tersebut diubah menjadi seperti gambar 2 . Jika nyala ke empat lampu dari kedua rangkaian tersebut diamati dengan baik, maka perubahan terang nyala lampunya dapat Anda gambarkan seperti diagram batang : ...... 


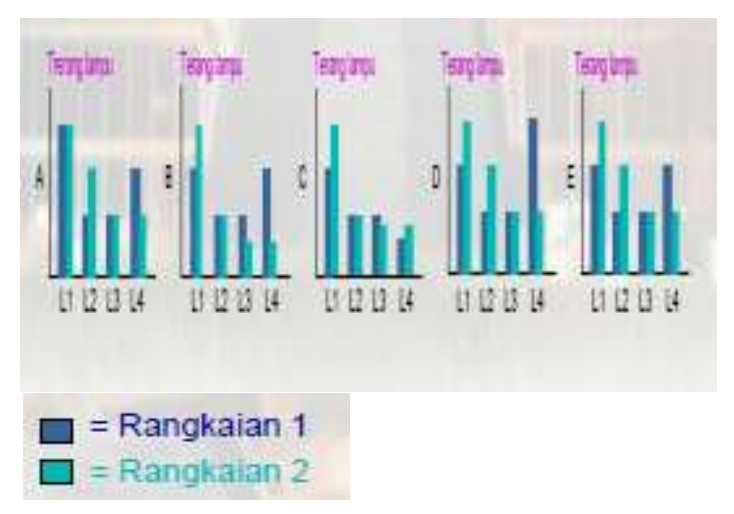

6. Keterampilan Menggunakan Alat dan Bahan

Keterampilan menggunakan alat dan bahan ini adalah keterampilan yang harus dimiliki oleh mahasiswa dalam menggunakan alat-alat, bahan-bahan percobaan sesuai dengan standar yang telah ditetapkan, Yolanda (2015), misalnya mahasiswa terampil dalam mengkalibrasi alat ukur sebelum digunakan dalam percobaan, mahasiswa terampil dalam membaca alat ukur, menentukan hasil pengukuran yang akurat, dan mahasiswa terampil dalam menggunakan alat ukur, bahan sesuai dengan prosedur keselamatan kerja.

\section{Keterampilan Merencanakan Percobaan atau Penyelidikian}

Keterampilan merencanakan percobaan dan penyelidikan ini adalah keterampilan yang harus dimiliki seorang saintis, Sandi (2013), misalnya keterampilan dalam menyusun prosedur kerja percobaan baik secara tertulis, membuat lembar kerja praktikum, terampil dalam menerapkan langkah-langkah percobaan sesuai standar operasional ilmiah, terampil dalam menentukan variabel terikat dan variabel bebas suatu penyelidikan/percobaan untuk diamati, diukur, atau ditulis, serta menentukan cara langkah kerja dan cara mengolah data.

\section{Keterampilan Berhipotesis}

Yolanda (2018) mendefinisikan Keterampilan berhipotesis merupakan keterampilan dalam merumuskan teori atau pendapat yang dianggap benar, yang kebenarannya masih harus dibuktikan. Sandi (2013) menyatakan hipotesis berbeda dengan prediksi. Hipotesis didasarkan pada pemahaman suatu teori atau konsep dengan metode deduktif, sedangkan prediksi didasarkan pada metode induktif. Misalnya memberikan jawaban sementara pada rangkaian lampu yang menyala jika saklar nya disambung seperti pada gambar.

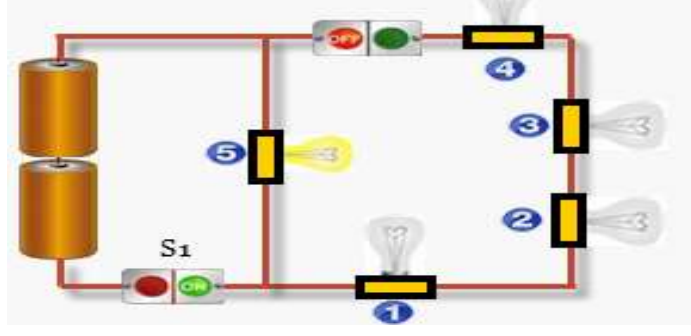

Jika salar S1 disambung, yang akan terjadi adalah...

a) semua lampu menyala

b) semua lampu padam

c) lampu 5 menyala, lampu 1, 2, 3, dan 4 padam

d) lampu 5 padam, lampu 1, 2, 3, dan 4 menyala

e) semua lampu padam

9. Keterampilan Menerapkan Konsep atau Prinsip

Keterampilan ini meliputi keterampilan menjelaskan peristiwa yang mereka alami dengan menerapkan konsep atau prinsip materi pembelajaran sejalan dengan pendapat Rustaman, dkk (2005) dan Sandi (2013). Mahasiswa terampil dalam memecahkan kasus dalam sebuah soal dengan cara menerapkan konsep yang telah dipelajari misalnya

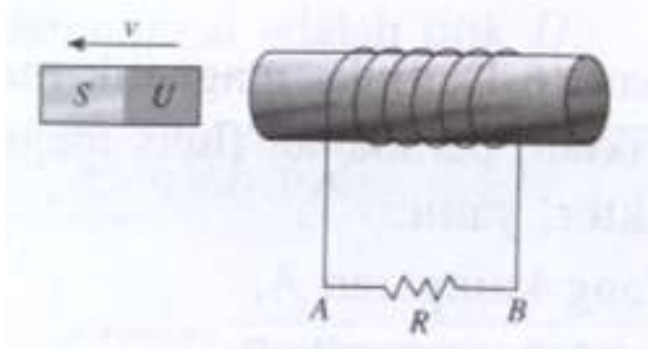

Apa yang terjadi jika magnet batang digeser menjauhi kumparan dan tentukan arah induksi pada hambatan? 
10. Keterampilan Berkomunikasi

Keterampilan berkomunikasi disini maksudnya mahasiswa terampil dalam menginformasikan hasil pengamatan, hasil prediksi atau hasil percobaan kepada orang lain termasuk keterampilan berkomunikasi dengan cara mendeskripsikan, membuat dan membaca tabel, membuat dan membaca grafik, membuat dan membaca diagram perbandingan hasil penelitian, ataupun gambar. Sandi (2013) menjabarkan bentuk komunikasi ini bisa dalam bentuk lisan dan tulisan. Jenis komunikasi dapat berupa paparan sistematis berupa laporan ataupun prosedur.

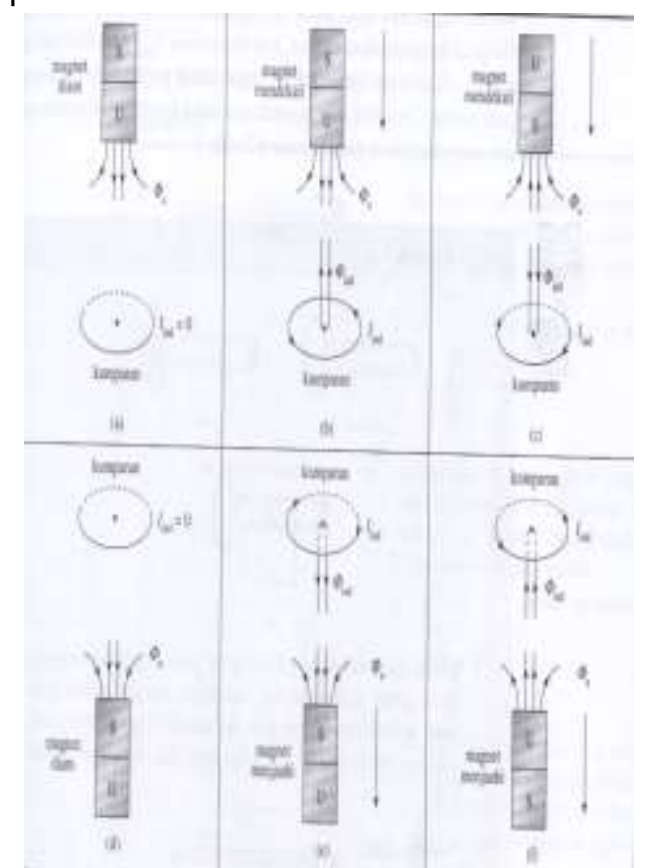

Jika GGL induksi timbul pada suatu rangkaian, maka arah arus induksi yang dihasilkan mempunyai arah sedemikian rupa sehingga menimbulkan medan magnetik induksi yang menentang perubahan medan magnetik (arah induksi berusaha mempertahankan fluks magnetik totalnya konstan). Coba saudara analisa untuk masing-masing gambar.

Berdasarkan beberapa solusi yang telah dipaparkan serta beberapa penelitian sebelumnya Saputra (2015), Sandi (2013) dan Yolanda (2018) menyimpulkan bahwa benar adanya keterampilan proses sains melibatkan keterampilan-keterampilan kognitif dan keterampilan psikomotorik melalui pembelajaran fisika berbasis keterampilan proses sains diharapkan dapat dikembangkan berbagai sikap ilmiah seperti kejujuran, ketelitian, dan tanggung jawab yang merupakan modal dasar dalam membangunan karakter peserta didik. Dari penjelasan tersebut maka dapat disimpulkan bahwa solusi untuk menyelesaikan permasalahan ketersediaan aspek keterampilan proses sains fisika mahasiswa pada pokok bahasan listrik magnet adalah melatih dan dilatih dengan pendekatan keterampilan proses sains fisika siswa agar ketersediaan aspek keterampilan proses sains siswa dapat muncul/tersedia. Adapun aspek KPS yang perlu dilatih dan melatih adalah keterampilan klasifikasi, mengkomunikasikan, berhipotesis, menerapkan konsep, bereksperimen, menggunakan alat dan bahan, interprestasi dan mengajukan pertanyaan.

\section{PENUTUP}

\section{SIMPULAN}

Berdasarkan hasil data penelitian KPS listrik magnet mahasiswa pada pokok bahasan Listrik magnet disimpulkan (1) Keterampilan proses sains listrik magnet mahasiswa pokok bahasan listrik magnet adalah terampil, dan (2) Solusi untuk menyelesaikan permasalahan ketersediaan aspek KPS adalah melatih dan dilatih dengan pendekatan KPS listrik magnet mahasiswa agar ketersediaan aspek KPS mahasiswa dapat muncul/tersedia. Adapun aspek KPS yang perlu dilatih dan melatih adalah keterampilan klasifikasi, mengkomunikasikan, berhipotesis, menerapkan konsep, bereksperimen, menggunakan alat dan bahan, interprestasi dan mengajukan pertanyaan. Rata-rata persentase peningkatan KPS yakni, keterampilan observasi $82 \%$, keterampilan klasifikasi $80 \%$, keterampilan interpretasi $85 \%$, keterampilan prediksi $78 \%$, keterapilan merencanakan percobaan atau penyelidikan $88 \%$, keterampilan menggunakan alat dan bahan $87 \%$, keterampilan menerapkan konsep atau prinsip $80 \%$, keterampilan berkomunikasi $85 \%$, keterampilan mengajukan pertanyaan 84 , dan keterampilan berhipotesis $79 \%$. 
Sehingga secara keseluruhan terjadinya peningkatan yang signifikan $82,8 \% \mathrm{KPS}$ mahasiswanya.

\section{SARAN}

Dari hasil penelitian ketersediaan keterampilan proses sains mahasiswa STKIP PGRI Lubuklinggau, peneliti memberikan sumbangsaran kepada pihak-pihak terkait antara lain sebagai berikut:

1. Mahasiswa, hendaknya untuk memahami dan menerapkan pembelajaran listrik magnet dengan melatih pendekatan keterampilan proses sains.

2. Dosen, hendaknya dosen menerapkan aspek KPS kepada mahasiswa agar mahasiswa membiasakan diri untuk terampil dalam proses pembelajaran sains.

3. Lembaga Pendidikan, menjadi pembekalan terhadap calon pendidik agar dapat menekankan pada aspek keterampilan proses sains mahasiswa.

4. Peneliti selanjutnya, penelitian ketersediaan aspek KPS mahasiswa selanjutnya memberikan variasi terhadapat penelitian tentang ketersediaan aspek keterampilan proses sains agar mahasiswa dapat terampil dalam keterampilan proses sains.

\section{UCAPAN TERIMAKASIH}

Ucapan terimakasih ini ditujukan kepada Kemenristekdikti dalam program hibah Penelitian Dosen Pemula (PDP), Kampus STKIP PGRI Lubuklinggau Program Studi Pendidika Fisika sehingga penelitian ini dapat berjalan.

\section{REFERENSI}

Chaedar. A. (2009). Tujuan Pendidikan Kontekstual. Bandung. Mizan Learning Centre.

Emzir. (2011). Metode Penelitian Kualitatif Analisis Data. Jakarta: raja Grafindo Persada.

Gall, M. D., Borg, W. R., \& Gall, J. P. (1996). Educational research: An introduction. Longman Publishing.

Gay, L.R. dan Geoffrey, E. Mills Peter Airasian. (2009). Educational Research: Competencies for Analysis and Applications. Colimbus Ohio. New Jersey.

Hilpan, M. (2014). Analisis Ketersediaan Keterampilan Proses Sains (KPS) dalam Buku Sekolah Elektronik (BSE) Fisika Kelas XI pada Konsep Fluida. Jurnal Pendidikan, 2, 24-48.

Nasution. (2012). Kurikulum Pengajaran. Jakarta:
PT Bumi Aksara

Nurhasanah. (2016). Penggunaan Tes Keterampilan Proses Sains (KPS) Siswa dalam Pembelajaran konsep Kalor dengan Model Inquiri Terbimbing. UIN Syarif Hidayatullah Jakarta. Retrieved from http://repository.uinjkt.ac.id/dspace/handle/1 23456789/31900

Pratama, A. A., Sudirman, \& Andriani, N., (2014). Studi Keterampilan Proses Sains pada Pembelajaran Fisika Materi Getaran dan Gelombang di Kelas VIII SMP Negeri 18 Palembang. Jurnal Inovasi dan Pembelajaran Fisika, 1(2), 137-144.

Rustaman, N., Dirdjosoemarto, S., Yudianto, S. A., Achmad, Y., Subekti, R., Rochintaniawati, D., \& Nurjhani, M. (2005). Strategi Belajar Mengajar Biologi. Malang: UNM

Sandi, M. I. (2013). Analisis Buku Ajar Fisika SMA Kelas $X$ di Kota Bandung Berdasarkan Kategori Literasi Sains (Doctoral dissertation, Universitas Pendidikan Indonesia).

Saputra, A. W. A. (2015). Analisis Keterampilan Proses Sains Siswa Sekolah Menengah Atas (SMA) di Kecamatan Andong Kabupaten Boyolali pada Mata Pelajaran Fisika (Doctoral dissertation, Universitas Negeri Semarang).

Serway, R. A., \& Jewett, J. W. (2009). Fisika untuk Sains dan Teknik. Jakarta: Salemba Teknika.

Setiawan, D. (2007). Pengembangan Bahan Ajar. Jakarta: Universitas Terbuka

Sugiyono. (2008). Metode Penelitian Pendidikan: Pendekatan Kuantitatif, Kualitatif, dan $R$ \& D. Bandung: Alfabeta.

Tomlinson, B. (2011). Materials Development in Language Teaching Comridge: University Press.

Yanti, A. I. R. (2013). Analisis Buku Pelajaran Fisika Sekolah Menengah Atas Kelas $X$ yang Banyak Digunakan di SMA Negeri SeKabupaten Kebumen (Doctoral dissertation, Universitas Negeri Semarang).

Yolanda, Y., \& Amin, A. (2018). Profil Keterampilan Proses Sains Fisika Siswa SMA di Kota Lubuklinggau pada Pokok Bahasan Listrik Dinamis. Thabiea: Journal of Natural Science Teaching, 1(2), 70-78.

Yolanda, Y. (2015). Keterampilan proses sains sebagai penilaian pembelajaranan sebagai implementasi Kurikulum 2013. In Seminar Nasional dan Lomba Media Pembelajaran, STKIP Lubuklinggau, Sumatera Selatan. 